\title{
A community-based education programme to reduce insecticide exposure from indoor residual spraying in Limpopo, South Africa
}

Brenda Eskenazi ${ }^{1 *}$, David I. Levine ${ }^{2}$, Stephen Rauch', Muvhulawa Obida ${ }^{3}$, Madelein Crause $^{3}$, Riana Bornman ${ }^{3,4}$ and Jonathan Chevrier ${ }^{5}$

\begin{abstract}
Background: Indoor residual spraying (IRS), the coating of interior walls of houses with insecticides, is common in malaria-endemic areas. While important in malaria control, IRS potentially exposes residents to harmful insecticides. The World Health Organization recommends steps to minimize exposure; however, no programme has focused on educating populations.
\end{abstract}

Methods: A dramatic presentation and song were developed by study personnel and performed by lay performers in order to spread awareness of the importance of IRS and to minimize insecticide exposure. Performances were staged at 16 sprayed villages in the Vhembe District of Limpopo, South Africa, at which 592 attendees completed short questionnaires before and after the performance about behaviors that might limit insecticide exposure. Overall indices of the attendees' change in knowledge of precautions to take prior to and after spraying to prevent insecticide exposure were analyzed using hierarchical mixed models to assess the effect of the performance on change in participants'knowledge.

Results: Approximately half of attendees lived in homes that had been sprayed for malaria and $62 \%$ were female. Over 90\% thought it better to allow IRS prior to the presentation, but knowledge of proper precautions to prevent exposure was low. The proportion answering correctly about proper distance from home during spraying increased from $49.4 \%$ pre-performance to $62.0 \%$ post-performance $(\mathrm{RR}=1.26,95 \% \mathrm{Cl}=1.13,1.41)$, and the proportion reporting correctly about home re-entry interval after spraying increased from 58.5 to $91.1 \%$ ( $R R=1.54,95 \% \mathrm{Cl} 1.35,1.77$ ). Attendees improved in their knowledge about precautions to take prior to and after spraying from mean of 57.9\% correct to a mean of $69.7 \%(\beta=12.1 \%, 95 \% \mathrm{Cl} 10.9,13.4)$. Specifically, increased knowledge in closing cupboards, removing food and bedding from the home, covering immoveable items with plastic, and leading animals away from the home prior to spraying were observed, as was increased knowledge in sweeping the floors, proper disposal of dead insects, and discarding dirty washrags after spraying.

Conclusions: A dramatic presentation and song were able to increase the attendees'knowledge of precautions to take prior to and after spraying in order to limit their insecticide exposure resulting from IRS. This approach to community education is promising and deserves additional study.

Keywords: Community education, Dramatic presentation, Indoor residual spraying, Insecticide exposure, Malaria prevention, Questionnaire, Vhembe, South Africa

\footnotetext{
*Correspondence: eskenazi@berkeley.edu

${ }^{1}$ Center for Environmental Research and Children's Health (CERCH),

School of Public Health, University of California at Berkeley, 1995

University Ave. Suite 265, Berkeley, CA 94704, USA

Full list of author information is available at the end of the article
} 


\section{Background}

In 2017, there were 219 million cases of malaria, resulting in about 435,000 deaths, with most deaths occurring to children under age 5 and living in sub-Saharan Africa [1]. Increased prevention and control measures have led to an overall reduction in global malaria mortality rate of about $60 \%$ since 2000 [1]. A total of 21 countries worldwide, including South Africa, were identified as likely to reach zero indigenous cases by 2020 [1]. However, South Africa is not on target to meet these World Health Organization (WHO) goals, having experienced a $>20 \%$ increase in cases between 2016 and 2017 [1]. Inadequate mosquito vector control, improved reporting, and climatic changes likely play a role in this increase [1]. In South Africa, there are three malaria-endemic provinces: Mpumalanga, KwaZulu-Natal, and Limpopo [2]. Between 2000 and 2010, Limpopo had the lowest decrease in malaria cases in South Africa [2], and between 2013 and 2014 malaria cases nearly doubled [3].

South Africa is part of the Elimination 8 (E8) Regional Initiative to jointly plan and execute a regional malaria elimination strategy for eight Southern African countries by 2030 [4]. The major components of the South Africa national policy for malaria elimination includes malaria vector control by indoor residual spraying (IRS), early detection by rapid diagnostic test (RDT), and artemisinin-based combination therapy. IRS is the systematic insecticide application to the interior walls of homes to kill malaria-infected mosquitoes as they rest. IRS with the organochlorine insecticide dichlorodiphenyltrichloroethane (DDT) has been ongoing since 1946 in malariaendemic regions of South Africa [5]. DDT and its main breakdown product, dichlorodiphenyldichloroethylene (DDE), have long half-lives in the human body (6 years and up to 10 years, respectively) and in the environment. Thus, the Stockholm Convention banned DDT for all uses except for public health purposes due to its toxicity [6-8]. In recent years, pyrethroid insecticides have been primarily used for IRS in South Africa [9]. In Vhembe, cypermethrin was used until 2015 and deltamethrin has been used since then. It is not South African policy to rotate pyrethroids or to distribute pesticide-impregnated bed nets.

Both DDT and pyrethroids are neurotoxic in developing animals through a number of mechanisms [9-11] and both DDT [12] and some pyrethroids [13] are endocrine disruptors. Thus, although effective prevention of malaria is of critical importance to human health, there is growing concern about the potential health effects of IRS insecticides [14, 15]. Previously, we have identified in a Vhembe birth cohort associations between DDT in maternal serum collected at delivery and increased maternal hypertension [16], childhood infections [17], and larger fetal and childhood growth in girls [18, 19]. Associations have also been found between pyrethroid metabolites in maternal urine and negative sequelae in their children, including impaired neurobehavioral development [20], and decreased childhood growth in boys [19].

A key goal of South Africa's Malaria Elimination Strategy is to ensure that by $2018,100 \%$ of the population has adequate malaria knowledge and practice [21]. To reach this goal, One Sun Health, a non-profit organization, developed a Malaria Awareness Programme (MAP) in the northern Vhembe region of Limpopo [22]. The curriculum for MAP included innovative methods to train home-based care, over multiple sessions, on malaria transmission. Teaching methods included visual diagrams, a song to teach symptoms, a drama to teach prevention, and a graphic to teach treatment. A number of other studies around the world have also investigated the effectiveness of education programmes in increasing knowledge of malaria symptomatology, prevention, and treatment [22-26] and several have used dramatic presentations or song to deliver the educational messages [27-29]. Although best practices to reduce exposure to insecticides were outlined by the WHO [30] and the President's Malaria initiative [31], no prior study has included in their education programme the prevention of insecticide exposure to residents from IRS.

This study examines the effectiveness of a dramatic presentation and song to convey to residents living in the Vhembe district municipality of Limpopo South Africa the importance of IRS for malaria control and ways to prevent insecticide exposure. Herein, the effectiveness of a single dramatic educational presentation is assessed in increasing knowledge of prevention of undue insecticide exposure to residents.

\section{Methods \\ Participants}

Participants were adults residing in 16 villages in the Thulamela region of the Vhembe District Municipality of Limpopo Province in South Africa where IRS was conducted (Fig. 1). Participants were mainly VhaVenda and spoke TshiVenda. Research staff personally invited women (with phone calls and in person) who had participated in the Venda Health Examination of Mothers, Babies and their Environment (VHEMBE) birth cohort study [20]. In addition, they were encouraged to invite friends, family, and other residents of their villages. The meetings were also promoted with posters and wordof-mouth campaigns by VHEMBE staff and local chiefs. Attendees who were able to read and write and 18 years or older were asked to complete a questionnaire both before and immediately after the presentation. Of the 


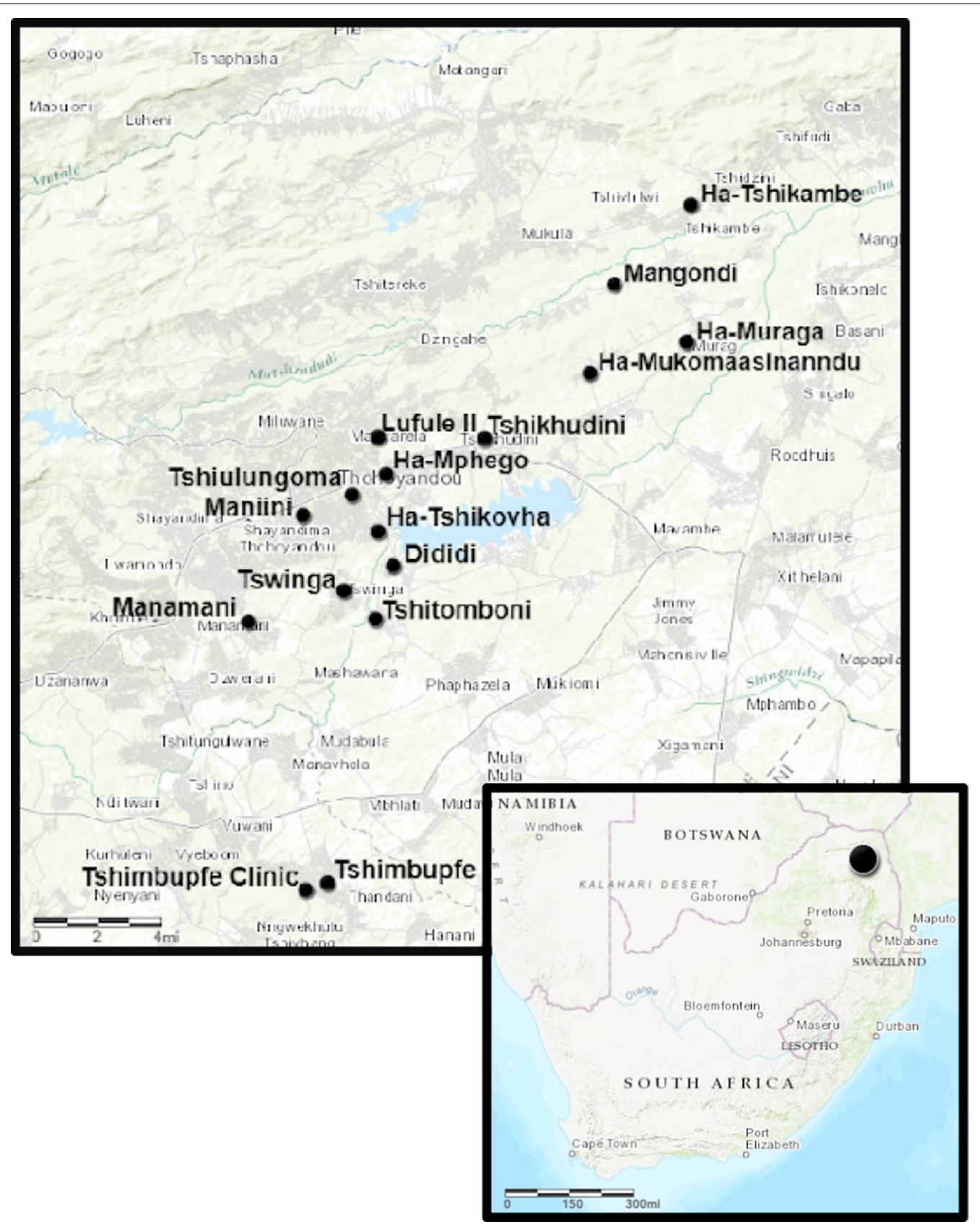

Fig. 1 Location and names of the villages in Limpopo South Africa where skit and song were performed

1068 adults who attended, 592 (55.4\%) completed the questionnaire both pre- and post-presentation.

\section{Educational programme}

The educational programme was conceptualized within the framework of the Health Belief Model [32, 33], a widely used value expectancy theory that aims to both predict and explain behavior. This theory suggests that people's propensity to individual health behaviour change depends on their perceptions of: (1) their susceptibility to a health risk or condition; (2) the severity of the risk or illness; (3) the benefits of taking action; and (4) the barriers or costs of acting [33]. Some theorists also emphasize the value of a "cue to action" which may motivate individuals to take a desired step. In this study, the educational intervention (performance and/or song) is both the means of providing knowledge and a "cue to action" encouraging or further reinforcing the desired health 


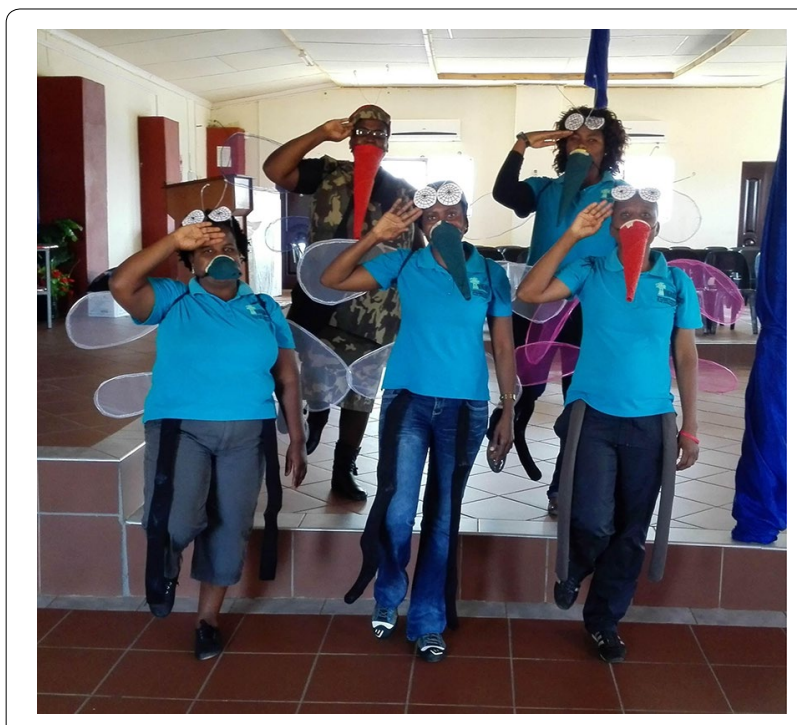

Fig. 2 Photograph of skit performers in costume

behaviour changes, i.e., allowing indoor home spraying but practicing protective measures in advance.

The education programme consisted of a skit followed by a song in TshiVenda. The purpose of the skit and song was to educate the audience on the importance of IRS for malarial control and on the necessary precautions in preventing undue insecticide exposure. The skit was developed at University of California Berkeley (D.I.L.). Then, feedback was elicited from the field office staff of approximately 10 individuals. The revised skit was then presented to patients and staff at the local hospital, as well as to drama students at the University of Pretoria. The skit was then revised based on this feedback. The song was developed by the field office staff based on the information in the skit. The skit and song were performed by VHEMBE study staff in costume as mosquitos (Fig. 2) and identified several precautions to be taken before and after spraying based on best practices outlined by the 2015 WHO Report [30].

The skit told a story about a mosquito army that sets out to spread malaria to the local village (see Appendix 1 for script in English and TshiVenda). The mosquitoes grow concerned when a loving mother tells her daughter how important it is to spray their home with insecticide. The daughter then provides several arguments against spraying: It will hurt her doll and her dog. The mosquito army cheers after each objection. Then the performers ask the audience for suggestions on how to keep toys safe from the spray. The mosquito army is sad when the mother points out-and acts out-that toys should be outside the home during the spraying. Performers identify and act out the WHO-recommended pre-spraying precautions and post-spraying behaviours that reduce exposure. At the end of the presentation, they sing a song reinforcing the overall message that IRS is beneficial and that everyone should minimize insecticide exposure to themselves and their families (see Appendix 2) (see videos of skit and song: https://www.youtube.com/watch ?v=lvZ1W5ZJM8Y; https://www.youtube.com/watch $? \mathrm{v}=$ S_gbrBxDGys). The skit and song were performed in churches or community halls; however, the video clips above were taken from performances in local schools (at which questionnaires were not collected) due to better sound quality.

\section{Evaluation of knowledge of precautions}

Each eligible participant was asked to complete a preand a post-performance questionnaire. The two sets of questions were identical (see Appendix 3) except that demographic information, such as sex, age group, and whether an attendee's home had been sprayed for malaria (regardless of whether they lived there at the time) were included in the pre-performance questionnaire. The preand post-performance questionnaires included questions about whether it was better to allow spraying for malaria control in their homes or not, the proper distance to stay from the home while spraying is occurring, and the length of time they should wait after spraying before reentering their homes. They were also given lists of behaviours (some helpful, some harmful, some neutral) for before and after spraying (12 each) and asked to indicate which they should do. All behaviours referred to in the questionnaire were touched upon in the skit and in the song.

Each participant was handed the pre-performance and post-performance questionnaires, with the latter folded and stapled closed so that the participant could not read it during the performance. Before the drama and song were begun the participants were asked to complete the pre-performance questionnaire. The staff then collected each of these pre-performance questionnaires. The drama and song were performed, and afterwards participants were asked to open the closed post-performance questionnaire and complete it; forms were again collected from each individual. During the completion of the questionnaires, study staff walked around to make sure that the participants would not instruct each other, copy from another, or complete the form for someone else. Instead, they were encouraged to ask staff if they needed clarification on how to complete the questionnaires; staff were not allowed to explain the meaning of the questions. Participants were asked to answer according to how they understood the questions.

No identifying information was collected. Verbal informed consent was obtained at the group level. 
As part of the opening remarks, the event facilitator explained the purpose of the questionnaire and emphasized that participation was voluntary. Verbal consent was implied by completion of the questionnaire. The questionnaire and consent procedures were approved by the Institutional Review Boards at the University of California, Berkeley and the University of Pretoria in South Africa.

\section{Statistical analysis}

For questions regarding gender, age, and whether the participant's home had been sprayed for malaria, invalid responses were set to missing. In all, there were 26 missing values for gender, 27 for age, and 38 for spray status.

Multiple-choice questions with a single correct answer were assessed using the proportion of correct responses before and after the presentation. As an overall measure, each attendee's total percent correct was calculated for questions involving all individual pre-spraying behaviours (out of 9), all post-spraying behaviours (out of 12), and overall (out of 21). The neutral behaviours (3 prespraying behaviours having no effect on exposure, e.g., serving tea to the spray workers) were not included in the percent correct. Each specific behaviour was also assessed comparing the correctness of an attendee's response pre- versus post-presentation.

The effect of the presentation was assessed by comparing responses before and after the presentation using hierarchical mixed models with random intercepts for the village and attendee, adjusted for age and gender. For multiple-choice questions with a single correct answer, relative risks (RR) of the probability of responding correctly were estimated, using binary models with a log link and Poisson distribution function, estimating standard errors using the Huber-White sandwich estimator [34, 35]. (Roughly, the RR represents the change in probability of a correct response, and an RR above 1 indicates an increased probability). For each attendee's percentage of correct responses (for pre-spraying behaviours, postspraying behaviours, and overall), mixed linear regressions were used to estimate the adjusted mean change $(\beta)$ as a result of the presentation. Relative risks of the probability of responding correctly to individual questions were also assessed, using the same binary-outcome models as described above. The effects of the presentation were assessed for the entire study population, as well as for the subset of participants who reported that their homes had been sprayed for malaria control.

\section{Results}

The number of participants returning surveys from each of the 16 villages ranged from 8 to 97 people per village (median is 24) (see Fig. 1 for a map of the villages). Nearly
Table 1 Demographic characteristics of presentation attendees, Limpopo, South Africa, 2015-2016

\begin{tabular}{lc}
\hline & N (\%) \\
\hline Sex $^{\mathrm{a}}$ & \\
Male & $217(38.3)$ \\
Female & $349(61.7)$ \\
Age $^{\mathrm{b}}$ & \\
$18-24$ & $127(22.5)$ \\
$25-30$ & $128(22.7)$ \\
$31-40$ & $120(21.2)$ \\
41 and older & $190(33.6)$ \\
Home ever sprayed for malaria?c & \\
Yes & $299(54.0)$ \\
No & $209(37.7)$ \\
Don't know & $46(8.3)$ \\
\hline
\end{tabular}

${ }^{a}$ Missing 26 values

${ }^{b}$ Missing 27 values

c Missing 38 values

two-thirds of participants (61.7\%) were female. Participants were fairly evenly distributed among age categories, with the largest number over 40 years. Slightly more than half of participants (54.0\%) reported currently living in homes that had ever been sprayed for malaria control (whether or not they lived there at the time) (Table 1).

Table 2 presents a comparison between the pre- and post-performance responses to questions about whether to allow IRS, their location during spraying, and the timing of re-entry into the home. Almost all thought it was better to have their home sprayed pre-performance, yet this percent increased slightly post-performance, from 95.1 to $98.1 \%(R R=1.03,95 \%$ CI $1.00,1.06)$ for all and from 97.2 to $99.3 \%(R R=1.02,95 \%$ CI $0.99,1.05)$ for those who had lived in a sprayed home. When asked about the distance they should stand from the home while spraying, the proportion answering correctly (a few metres away) went from $49.4 \%$ pre-performance to $62.0 \%$ post-performance $(R R=1.26,95 \% \mathrm{CI} 1.13,1.41)$ for all and $48.9 \%$ to $59.1 \%(R R=1.24,95 \%$ CI $1.06,1.44)$ for occupants of homes ever sprayed. When asked how soon they should wait to re-enter their homes after spraying, $58.5 \%$ gave the correct answer (at least an hour) before the presentation but $91.1 \%$ did so afterwards $(R R=1.54$, $95 \%$ CI $1.35,1.77)$ for the entire group and increased from 57.1 to $91.9 \%(R R=1.61,95 \%$ CI $1.42,1.82)$ for occupants of homes that had ever been sprayed.

Table 3 presents overall summaries of knowledge before and after the presentation. The rate of correct answers for precautions to take before spraying improved from a mean of $59.9 \%$ before the presentation to $72.4 \%$ afterwards $(\beta=12.8 \%, 95 \%$ CI $11.0,14.7)$ for all 
Table 2 Proportion of correct responses to questions about home spraying: pre- and post- performance, Limpopo South Africa, 2015-2016

\begin{tabular}{|c|c|c|c|c|c|c|c|}
\hline \multirow[t]{2}{*}{ Question } & \multirow[t]{2}{*}{ Correct response } & \multicolumn{3}{|c|}{ All (\% correct) } & \multicolumn{3}{|c|}{$\begin{array}{l}\text { With sprayed homes (\% } \\
\text { correct) }\end{array}$} \\
\hline & & Pre & Post & $\mathrm{RR}(95 \% \mathrm{Cl})^{\mathrm{a}}$ & Pre & Post & $\operatorname{RR}(95 \% \mathrm{Cl})^{\mathrm{a}}$ \\
\hline Better to allow spraying for malaria control in home? & Yes & 95.1 & 98.1 & $1.03(1.00,1.06)^{*}$ & 97.2 & 99.3 & $1.02(0.99,1.05)$ \\
\hline $\begin{array}{l}\text { How close do you think you should be to your home while it is } \\
\text { being sprayed? }\end{array}$ & A few meters away & 49.4 & 62.0 & $1.26(1.13,1.41)^{*}$ & 48.9 & 59.1 & $1.24(1.06,1.44)^{*}$ \\
\hline $\begin{array}{l}\text { How soon after a spraying do you think it is okay to enter your } \\
\text { home? }\end{array}$ & After at least an hour & 58.5 & 91.1 & $1.54(1.35,1.77)^{*}$ & 57.1 & 91.9 & $1.61(1.42,1.82)^{*}$ \\
\hline
\end{tabular}

${ }^{*} \mathrm{p}<0.05$

a Adjusted for sex and age, using mixed-effects models with a random intercept for village and attendee

Table 3 Comparison of percent correct to all pre- and post-performance spraying precaution questions and for all precautions

\begin{tabular}{|c|c|c|c|c|c|c|c|}
\hline \multirow[t]{2}{*}{ Precaution } & \multirow[t]{2}{*}{ Maximum } & \multicolumn{3}{|c|}{ All (\% correct) } & \multicolumn{3}{|c|}{ With sprayed homes (\% correct) } \\
\hline & & Pre & Post & $\beta(95 \% \mathrm{Cl})^{\mathrm{a}}$ & Pre & Post & $\beta(95 \% \mathrm{Cl})^{\mathrm{a}}$ \\
\hline Pre-spraying & 9 & 59.9 & 72.4 & $12.8(11.0,14.7)^{*}$ & 60.6 & 73.8 & $13.3(10.5,16.1)^{*}$ \\
\hline Post-spraying & 12 & 56.5 & 67.7 & $11.6(9.8,13.3)^{*}$ & 57.5 & 69.4 & $12.0(8.7,15.3)^{*}$ \\
\hline All precautions & 21 & 57.9 & 69.7 & $12.1(10.9,13.4)^{*}$ & 58.8 & 71.3 & $12.5(9.6,15.4)^{*}$ \\
\hline
\end{tabular}

*p $<0.05$

${ }^{\text {a }}$ Models adjusted for sex and age, using mixed-effects models with a random intercept for village and attendee

participants and from a mean of 60.6 to $73.8 \%(\beta=13.3 \%$, $95 \%$ CI 10.5, 16.1) for those who lived in sprayed homes. Correct responses for post-spraying precautions increased significantly from $56.5 \%$ before the presentation to $67.7 \%$ afterwards $(\beta=11.6 \%, 95 \%$ CI $9.8,13.3)$ for all participants and from 57.5 to $69.4 \%(\beta=12.0 \%, 95 \% \mathrm{CI}$ $8.7,15.3)$ for those who lived in sprayed homes. Overall correct answers increased from 57.9 to $69.7 \%(\beta=12.1 \%$, $95 \%$ CI $10.9,13.4)$ for all participants and from 58.8 to $71.3 \%$ ( $\beta=12.5 \%, 95 \%$ CI 9.6, 15.4) for those who lived in sprayed homes.

The knowledge of attendees for individual pre-spraying precautions significantly improved post-presentation for many, but not for all, of the key items recommended by the WHO. In particular, significantly increased knowledge was observed for removing food from the home, closing cupboards, removing bedding, covering immoveable items with a plastic sheet, and leading animals away from the home (see Table 4). There was no significant improvement in knowledge to remove drinking water and children's toys from the home. In addition, there was no change in knowledge for the neutral items that we included (e.g., cleaning and waxing floors). Although there was significant improvement in knowledge about what precautions to take before spraying, even after the presentation less than $70 \%$ of the participants knew key precautions to take before IRS, such as closing cupboards, removing bedding, covering immoveable items with plastic, and leading animals away. When considering only respondents living in homes that had previously been sprayed, the results were similar.

Of post-spraying behaviours, knowledge improved for sweeping the floors and proper disposal of dead insects (burning or discarding them in the latrine; not feeding them to animals or discarding them in the waste heap). They showed improvement in knowing to discard washrags after using them rather than rinsing them and using again, as well as not washing the walls with soap and water. However, no improvement was noted in the participants' knowledge that they should clean children's toys and wash inside furniture or floors with soap and water. Although there was significant improvement in knowledge about some precautions to take after spraying, less than $70 \%$ of the participants knew after the presentation to burn dead insects, sweep and wash their floors, wash indoor furniture, discard washing rags, and to wash children's toys. When considering only respondents living in homes that they had reported as previously sprayed, the results were similar. 


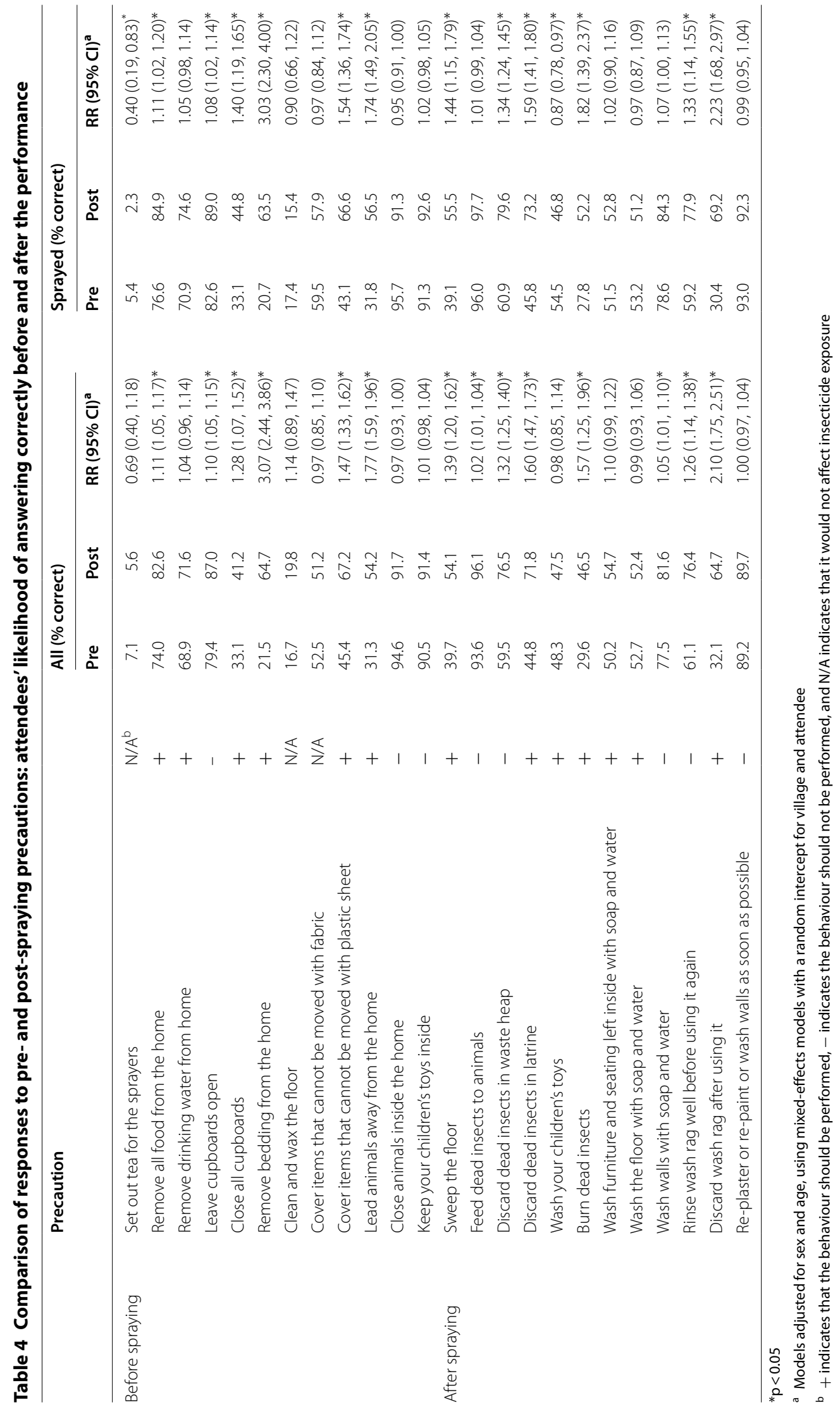




\section{Discussion}

Acceptance of IRS was very high both before and after the skit. However, a brief dramatic presentation and song performed by research study staff, who were not formally trained in the performing arts and wearing simple costumes, was an inexpensive method to increase overall knowledge about ways to prevent undue insecticide exposure from IRS in communities such as those in Limpopo, South Africa. Specifically, knowledge increased after the skit and song about appropriate length of reentry interval and distance of residents from the spraying as well as for a number of precautions recommended by WHO: closing cupboards, removing bedding, covering immoveable items with plastic tarps, and leading animals away from the home before spraying, and proper disposal of dead insects and insecticide-contaminated wash rags after spraying. However, there was no demonstrable increase in knowledge for other measures recommended by WHO, such as removing drinking water from the home before spraying or cleaning children's toys, inside furniture, or floors after spraying. It is possible that there was no increase in knowledge about washing floors, or that participants may have known that floors should be washed but their homes' mud or daub floors were not washable.

Use of entertaining skits, song, and other folk media [29] to convey public health messages has been employed as a community engagement method in promoting public health and in preventing disease such as of HIV/AIDS [36-39] or tuberculosis [40]. These methods are often used to reach young, low-literacy, or other traditionally hard-to-reach populations [39, 41]. The Program for Appropriate Technology in Health (PATH) developed an approach in Zambia, using drama for malaria education tailored to local language through skits, songs, and dance [42]. However, only a few previous investigations have evaluated the dramatic arts in malaria education. Specifically, a drama performed by professional actors was employed in 20 Cambodian villages to promote the use of insecticide-treated bed nets (ITN), repellents, and early diagnosis; the villagers reported that drama was their preferred choice of community engagement [29]. Using folk theater (Kalajatha) in rural India, 30 local performance artists performed songs, a drama, and a musical drama focused on the transmission, signs, treatment, and prevention of malaria. After 2 months of performances, households from 5 intervention and 5 control villages were interviewed [28]. Although the intervention respondents significantly gained knowledge compared to controls, they did not show immediate behavioral change. In a study from Ghana [27], teachers trained an intervention group of school-age children with picture charts, posters, dramatization, and song on malaria symptoms, treatment and prevention, who then educated adults in their villages with song, poetry recitals, and drama. Adults in the intervention communities significantly increased their knowledge as well as use of ITN, and children from these communities had lowered parasite prevalence compared to prior to the intervention and to control children. The WHO 2015 operational manual for IRS acknowledged the need for community participation and coordination for effective IRS education, and Atkinson et al. [43], in a review of the literature, concluded that community engagement and participation is an essential component of malaria education and ultimate elimination. Most malaria educational intervention studies have employed intensive and expensive means to inform populations, often with multiple in-person sessions using highly-trained personnel or using multiple media such as radio, posters, and booklets [44]. Overall, most educational interventions have resulted in modest, although in some cases statistically significant, increases in knowledge of malaria prevention, symptoms, or treatment [45]. No previous study has compared the efficacy of the various modalities in engaging communities and in malaria education.

The skit-based educational programme was limited. Although knowledge of participants was compared preand post-performance, we did not compare change in the intervention-sprayed communities with a change after a sham presentation in a control group from sprayed communities. Given that the presentation sought to encourage IRS while preventing undue insecticide exposure, not much information about malaria symptomatology, prevention, or treatment was provided. Future dramatic presentations could be supplemented to include more information. In addition, estimates of learning may be biased by non-random selection of who turned in the questionnaire. For example, it is plausible respondents low in literacy did not return the survey, although this group may have most benefited from this form of education. It is also plausible that those who learned the least or left early may not have turned in their questionnaire forms. The evaluation of the success of this programme was also limited in that the increase in knowledge was measured immediately after the presentation. Hence, it is not clear whether the attendees retained the new lessons and, most importantly, whether there was a behavioral change in precautionary practices. Time constraints did not allow for the collection of information on attendees' 
confidence in their ability to perform safety measures, or any barriers that may exist to their implementation. Ideally, qualitative data collection should be considered to better understand barriers to implementation. The ultimate indicator of success of the programme would be to demonstrate a decrease in insecticide body burden [45-47].

However, there are a number of strengths of this study, including the large sample size and the low cost of a single brief training using lay presenters, rather than professional actors or singers. The presentations were brought to the communities, so large numbers of people could be educated at one time. Thus, this education programme can be readily reproduced even at a larger country-wide scale relatively cheaply using community members to perform the skit and teach the song. Other media or venues should also be explored such as on radio or in churches. Furthermore, although the entertainment value of the presentation was not formally assessed, anecdotal observation by staff and on recorded videotapes of the audience indicated that the attendees paid attention and many were laughing, clapping throughout, and joining in the song. In these low-income communities, where there is low employment and few entertainment options, the presentation provides an opportunity to provide entertaining health education tailored to the culture.

\section{Conclusions}

A single brief dramatic presentation and song was able to increase knowledge of precautions Limpopo villagers could take to reduce insecticide exposure from IRS and its potential adverse health outcomes. Future studies should evaluate whether this method of education results in sustained knowledge and in reduction in insecticide exposure. This approach to community education is promising and deserves additional study and potential expansion to include general information about malaria prevention, symptomatology, and treatment.

\section{Abbreviations}

Cl: confidence interval; DDE: dichlorodiphenyldichloroethylene; DDT: dichlorodiphenyltrichloroethane; IRS: indoor residual spraying; ITN: insecticidetreated bed nets; MAP: Malaria Awareness Programme; PATH: Program for Appropriate Technology in Health; RR: relative risk; VHEMBE: Venda Health Examination of Mothers, Babies and their Environment; WHO: World Health Organization.

\section{Acknowledgements}

We would like to acknowledge the VHEMBE field staff. Funding for this research was received from the National Institute of Environmental Health Sciences, Award ID: 1R01ES020360-01 (Eskenazi) and the Canada Research Chairs program (Chevrier).

\section{Authors' contributions}

BE served as the principal investigator of the VHEMBE study, from which the dramatic performance was produced. She is also the primary author of this manuscript. DL created the skit and provided important feedback of the manuscript, including the statistical analysis. SR served as the statistical analyst for the results presented here. $\mathrm{MO}$ and $\mathrm{MC}$ served as the field office coordinators for the VHEMBE study, and were instrumental in the creation of costumes and song, planning and performance of the dramatic presentation. $\mathrm{MO}$ provided translations for the script and song used in the performance. RB served as an advisor for the VHEMBE study in South Africa and in relations to community leaders. JC is an investigator on the VHEMBE study who provided key information on the intervention. All authors provided significant contributions and feedback on the manuscript. All authors read and approved the final manuscript.

\section{Funding}

Funding for this research was received from the National Institute of Environmental Health Sciences, Award ID: 1R01ES020360-01 (Eskenazi) and the Canada Research Chairs program (Chevrier).

\section{Availability of data and materials}

The datasets used for the analysis can be provided by the corresponding author on reasonable request. Data from individual questionnaires is not available due to privacy reasons.

\section{Ethics approval and consent to participate}

The study was approved by the Institutional Review Boards at the University of California, Berkeley and the University of Pretoria in South Africa. All participants provided verbal informed consent for participation.

\section{Consent for publication}

No identifiable data were collected and no individuals' data is presented, so consent for publication was not needed.

\section{Competing interests}

The authors declare that they have no competing interests.

\section{Author details}

${ }^{1}$ Center for Environmental Research and Children's Health (CERCH), School of Public Health, University of California at Berkeley, 1995 University Ave. Suite 265, Berkeley, CA 94704, USA. ${ }^{2}$ Haas School of Business, University of California at Berkeley, Berkeley, CA, USA. ${ }^{3}$ University of Pretoria Institute for Sustainable Malaria Control, School of Health Systems and Public Health, University of Pretoria, Pretoria, South Africa. ${ }^{4}$ Department of Urology, University of Pretoria, Pretoria, South Africa. ${ }^{5}$ Department of Epidemiology, Biostatistics and Occupational Health, McGill University, Montréal, QC, Canada. 


\section{Appendix 1a: Pre- and post-performance questionnaires in English}

\section{WELCOME TO THE VHEMBE DRAMA. \\ PLEASE TELL US A LITTLE ABOUT YOURSELF.}

\begin{tabular}{|ll|ll|}
\hline 1. What is your age group? & $\square$ 18-24 years & 2. Are you...? & $\square$ Male \\
& $\square 25-30$ years & & $\square$ Female \\
\cline { 3 - 4 } & $\square 31-40$ years \\
& $\square 41$ years or older & $\begin{array}{l}\text { 3. Has the home you live } \\
\text { in now ever been sprayed } \\
\text { to control malaria? }\end{array}$ & $\square$ Yes \\
& & $\square I$ don't know
\end{tabular}

\section{What do you think?}

\section{Is it better to ... $\quad \square$ Allow spraying for malaria control \\ $\square$ Refuse spraying}

\section{What are some good things to do BEFORE your home is sprayed? (YOU CAN CHECK MORE THAN ONE.) \\ $\square$ Set out tea for the sprayers $\quad \square$ Close all cupboards \\ $\square$ Remove all food from the home \\ $\square$ Remove drinking water from home \\ $\square$ Leave cupboards open \\ $\square$ Remove bedding from the home \\ $\square$ Clean and wax the floor \\ $\square$ Cover items that cannot be moved with fabric \\ $\square$ Cover items that cannot be moved with plastic sheet \\ $\square$ Lead animals away from the home \\ $\square$ Close animals inside the home \\ $\square$ Keep your children's toys inside}

\section{How close do you think you should you be to $\quad \square$ Okay to stay inside to assist sprayers your home while it is being sprayed? (CHECK $\square$ Okay to stand at door to watch ONE) \\ $\square$ A meter away \\ $\square$ A few meters away}

\section{How soon after a spraying do you think it is okay to enter your home? (CHECK ONE)
$\square$ Right away
$\square$ After 10 minutes
$\square$ After 30 minutes
$\square$ After at least 1 hour

\section{What are some good things to do AFTER your home is sprayed? (YOU CAN CHECK MORE THAN ONE)}

$\square$ Sweep the floor

$\square$ Feed dead insects to animals

$\square$ Discard dead insects in waste heap

$\square$ Discard dead insects in latrine

$\square$ Wash your children's toys $\square$ Burn dead insects

$\square$ Wash furniture and seating left inside with soap and water

$\square$ Wash floor with soap and water

$\square$ Wash walls with soap and water $\square$ Rinse wash rag well before using it again

$\square$ Discard wash rag after using it

$\square$ Re-plaster or re-paint or wash walls as soon as possible 
THANK YOU FOR LISTENING.

WE HOPE YOU ENJOYED THE DRAMA!

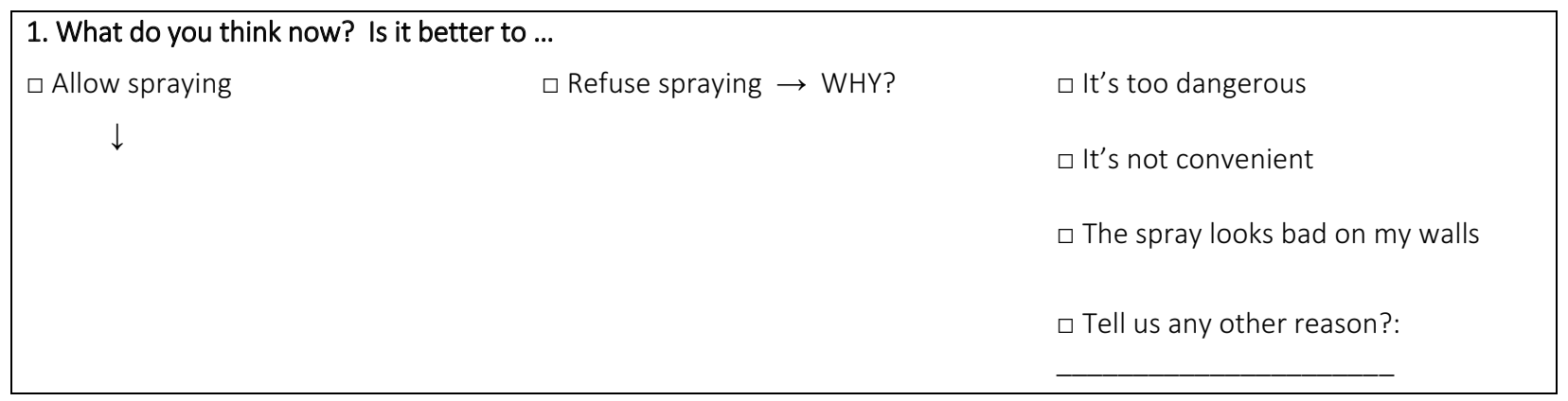

\begin{tabular}{|lll}
\hline 2. What are some good things to do BEFORE your home is sprayed? (YOU CAN CHECK MORE THAN ONE.) \\
$\square$ Set out tea for the sprayers & $\square$ Close all cupboards & $\square$ Cover items that cannot be moved \\
$\square$ Remove all food from the home & $\square$ Remove bedding from the home & with plastic sheet \\
$\square$ Remove drinking water from home & $\square$ Clean and wax the floor & $\square$ Lead animals away from the home \\
$\square$ Leave cupboards open & $\square$ Cover items that cannot be moved & $\square$ Close animals inside the home \\
& with fabric & $\square$ Keep your children's toys inside
\end{tabular}

\section{How close do you think you should you be to $\quad \square$ Okay to stay inside to assist sprayers your home while it is being sprayed? (CHECK $\square$ Okay to stand at door to watch ONE) \\ $\square$ A meter away \\ $\square$ A few meters away}

\section{How soon after a spraying do you think it is okay to enter your home? (CHECK ONE)
$\square$ Right away
$\square$ After 10 minutes
$\square$ After 30 minutes
$\square$ After at least 1 hour

\section{What are some good things to do AFTER your home is sprayed? (YOU CAN CHECK MORE THAN ONE) \\ $\square$ Sweep the floor $\quad \square$ Burn dead insects \\ $\square$ Feed dead insects to animals \\ $\square$ Discard dead insects in waste heap \\ $\square$ Discard dead insects in latrine \\ $\square$ Wash your children's toys \\ $\square$ Wash furniture and seating left inside with soap and water \\ $\square$ Wash floor with soap and water \\ $\square$ Wash walls with soap and water \\ $\square$ Rinse wash rag well before using it again \\ $\square$ Discard wash rag after using it \\ $\square$ Re-plaster or re-paint or wash walls as soon as possible}

Take home a brochure on spray safety and share it with your family. 


\section{Appendix 1b: Pre- and post-performance questionnaires in TshiVenda}

\section{Vho tanganedzwa litambwani la VHEMBE \\ Ri humbela vha ri vhudze zwittukuttuku nga ha vhone vhane.}

\begin{tabular}{|c|c|c|c|}
\hline \multirow[t]{2}{*}{$\begin{array}{l}\text { 1. Thanga ya murole } \\
\text { wavho ndi ifhio? }\end{array}$} & $\begin{array}{l}\square \text { Miniwaha ya } 18-24 \\
\square \text { Miniwaha ya } 25-30\end{array}$ & 2. Vha ...? & $\begin{array}{l}\square \text { Munna } \\
\square \text { Mufumakadzi }\end{array}$ \\
\hline & $\begin{array}{l}\square \text { Miniwaha ya } 31-40 \\
\square \text { Miniwaha ya } 41 \text { years na u fhira }\end{array}$ & $\begin{array}{l}\text { 3. Haya hune vha dzula } \\
\text { khaho zwino ho no } \\
\text { vhuya ha fafadzelelwa u } \\
\text { langula dali? }\end{array}$ & $\begin{array}{l}\square \text { Hai } \\
\square \text { Ee } \\
\square \text { A thi divhi }\end{array}$ \\
\hline
\end{tabular}

Zwi tevhelaho vha zwi vhonisa hani?

4. Ndi khwine u ... $\quad \square$ U tendela mufafadzelo wa vhulanguladali

$\square$ U hana mufafadzelo wa vhulanguladali

5. Ndi zwińwe zwithu zwifhio zwavhudi zwine zwa fanela u itiwa PHANDA ha musi haya havho hu tshi fafadzelwa? (VHA NGA NANGA DZINO FHIRA NTHIHI)

$\square$ U itela vhafafadzeli tie

$\square$ Bviselani zwiliwa zwothe nnda ha nndu

$\square$ Bviselani madi a u nwa nnda ha nndu

$\square$ Siani dziraga na wadirobo dzo vulea $\square$ Valani dziraga na wadirobo dzothe.

$\square$ Bviselani dzinguvho na malagane nnda ha nndu

$\square$ Koropani ni dodze pholishi fhasi

$\square$ Tibedzani zwithu zwothe zwi sa bvselei nnda nga labi $\square$ Tibedzani zwithu zwothe zwi sa bvisei nga seila la pulasitiki

$\square$ Khadelani zwifuwo kule na nndu

$\square$ Valelani zwifuwo ngomu nduni

$\square$ Vheyani thoyi dza vhana ngomu nduni.

\section{Vha humbula uri vha tea u vha vha tsini na nndu yavho nga mithara mingafhani musi hu tshi khou fafadzelwa? (NANGANI NTHIHI)
$\square$ Zwo luga u dzula ngomu nduni u thusa vhafafadzeli
$\square$ Zwo luga u ima munangoni vha talela
$\square$ Kule nga mithara muthihi
$\square$ Mimithara yo vhalaho

\section{Vha humbula ndi lini hune zwo luga uri vha dzhene nduni yavho? (NANGANI NTHIHI)
$\square$ Zwezwo vha tshi tou fhedza
$\square$ Nga murahu ha miminete ya 10
$\square$ Nga murahu ha miminete ya 30
$\square$ Nga murahu ho no fhela zwaho awara 1

$\begin{array}{ll}\text { 8. Ndi zwifhio zwavhudi zwine vha tea u ita NGA MURAHU HA musi haya havho vhu } \\ \text { NO FHIRA NTHIHI) } & \square \text { U fhisa zwikhokhonono zwo faho } \\ \square \text { U swiela fuloro } & \square \text { Tanzwani fanitshara na zwidulo zwo } \\ \square \text { U nea zwifuwo zwikhokhonono zwo } & \text { salaho nduni madini are na tshisibe } \\ \text { faho } & \square \text { Koropani dzifuloro nga tshisibe na } \\ \square \text { Lațani zwikhokhonono zwo faho } & \text { madi } \\ \text { daledaleni } & \square \text { Tanzwani mbondo nga tshisibe na } \\ \square \text { Posani zwikhokhonono zwo faho } & \text { madi } \\ \text { thoilethe ya dindi } & \end{array}$

$\square$ Tanzwani thoyi dza vhana $\square$ T्रukisani labi nga maanda ni saathu u dovha na li shumisa hafhu $\square$ Latani labi la u koropa nga murahu ha u li shumisa

$\square$ Pulasitelani kana ni penndulule kana u tanzwa mbondo nga u tavhanya 
RO LIVHUWA VHO RI THETSHELESA. RI A KHOLWA VHO DIPHINA NGA L्रITAMBWA!

\begin{tabular}{|c|c|c|}
\hline $\begin{array}{c}\text { Vha humbula hani zwino? } \\
\text { } \square \text { Tenda u fafadzelelwa } \\
\downarrow\end{array}$ & $\square$ Hana u fafadzelelwa $\rightarrow$ NGANI? & $\begin{array}{l}\square \text { Zwi khombosa } \\
\square \text { A zwi na mushumo } \\
\square \text { Mufafadzelo wo vhifha kha mbondo } \\
\text { dzanga } \\
\square \text { Zwinnwe zwiitisi-vho?: }\end{array}$ \\
\hline
\end{tabular}

Ndi zwiniwe zwithu zwifhio zwavhudi zwine zwa fanela u itiwa PHANDA ha musi haya havho hu tshi fafadzelwa? (VHA NGA NANGA DZINO FHIRA NTHIHI)

$\square$ U itela vhafafadzeli tie

$\square$ Bviselani zwiliwa zwothe nnda ha nndu

$\square$ Bviselani madi a u nwa nnda ha nndu

$\square$ Siani dziraga na wadirobo dzo vulea $\square$ U itela vhafafadzeli tie

$\square$ Bviselani zwiliwa zwothe nnda ha nndu

$\square$ Bviselani madi a u nwa nnda ha nndu

$\square$ Siani dziraga na wadirobo dzo vulea $\square$ U itela vhafafadzeli tie

$\square$ Bviselani zwiliwa zwothe nnda ha nndu

$\square$ Bviselani madi a u nwa nnda ha nndu $\square$ Siani dziraga na wadirobo dzo vulea
3. Vha humbula uri vha tea $u$ vha vha tsini na
$\square$ Zwo luga u dzula ngomu nduni u thusa vhafafadzeli nndu yavho nga mithara mingafhani musi hu tshi khou fafadzelwa? (NANGANI NTHIHI)
$\square$ Zwo luga u ima munangoni vha talela
$\square$ Kule nga mithara muthihi
$\square$ Mimithara yo vhalaho

\section{Vha humbula ndi lini hune zwo luga uri vha $\square$ Zwezwo vha tshi tou fhedza dzhene nduni yavho? (NANGANI NTHIHI) \\ $\square$ Nga murahu ha miminete ya 10 \\ $\square$ Nga murahu ha miminete ya 30 \\ $\square$ Nga murahu ho no fhela zwaho awara 1}

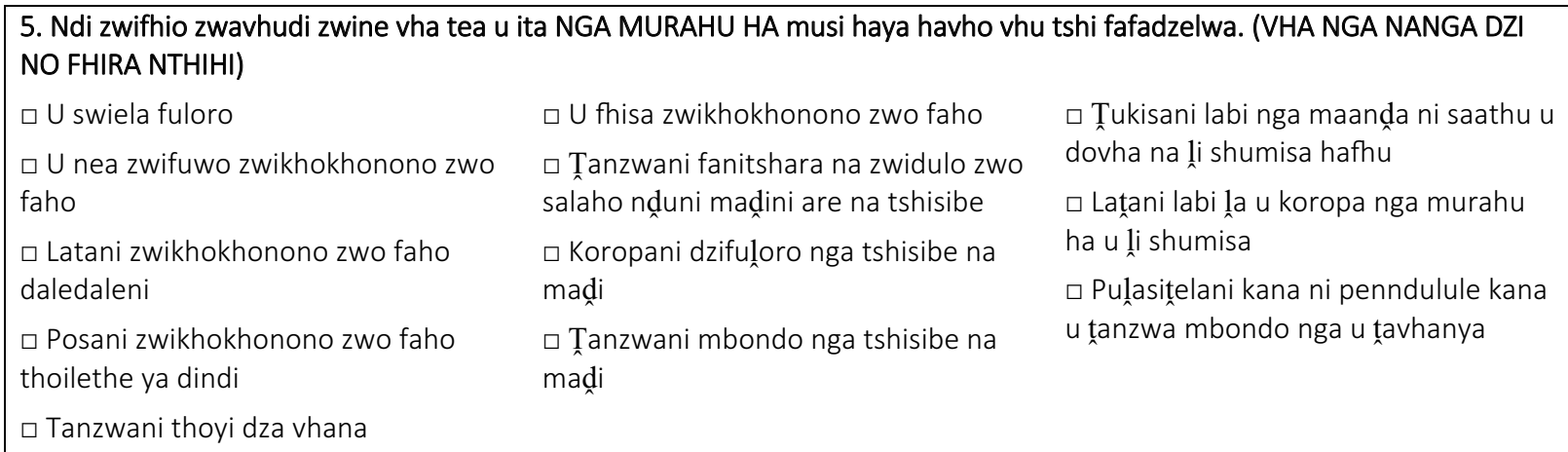

Kha vha dzhie bammbiri nga ha tsireledzo kha mufafadzelo vha tuwe nayo hayani vha i vhale na vha muta wavho. KHA VHA TSIRELEDZE MUTA WAVHO KHA DALI! 


\section{Appendix 2: Script of the skit performed by VHEMBE staff}

A sample clip from the performance can be found at https://www.youtube.com/watch?v=lvZ1W5ZJM8Y

A script to teach about malaria and how to stay safe
from pesticides
-ENGLISH-

General Trouble meets her Match:

David I. Levine

Announcer: As icebreaker-ask children a few questions to make sure they have an idea about malaria:

1. Who knows what malaria is?

2. How do we get malaria?

Announcer: We want to tell you a story about a mosquito army and things mummies can do to protect you against malaria and malaria spray.

Are you ready?

\section{Mosquito army headquarters}

[A general is addressing a line of new recruits.]

Mosquito General: Welcome new recruits. I am General Trouble. I command the most deadly army that has ever lived. My mosquito army has killed more people than all the wars of the world combined!

$$
\begin{aligned}
& <<\text { Mosquito soldiers cheer! }>> \\
& <<\text { Images of aerial fleet of mosquitos in military } \\
& \text { formation }>>
\end{aligned}
$$

Junior mosquito: How did we do that, General?

General: Let me tell you. Before I lay eggs, I need a great big meal. And my favorite big meal is human blood. I fly to a human- usually one that is sleeping.
Litambwa la u funza nga ha dali na u tsireledza vhathu kha zwivhulayazwikhokhonono

$$
\text { -TSHIVENDA- }
$$

\section{Mulangammbi vho-Khakhathi vha wana mukhaedu wavho}

David I. Levine

Mudivhadzi:Sa mvulatswinga - vhudzisani vhana mbudziso dzi si gathi uri ni vhe na vhutanzi uri vha na helwa nga ha dali:

1. Ndi nnyi ane a divha uri dali ndi mini?

2. Ri wana dali?

Mudivhadzi: Ri tama u ni vhudza nganea nga ha mmbi ya vhunyunyu na zwithu zwine vho-mme vha nga zwi ita u ni tsireledza kha dali na mufafadzelo wa vhunyunyu.

No luga?

\section{Gammbani khulwane ya vhunyunyu}

[Mulangammbi u khou amba na maswole maswa mufoloni.]

Mulanga mmbi wa vhunyunyu: No tanganedzwa maswole maswa. Ndi nne Mulangammbi Khakhathi. Ndi ranga phanda mmbi ya khombosa kha mmbi dzothe dzo no vhuyaho dza vha hone. Mmbi yanga ya vhunyunyu yo no vhulaha vhathu vha no fhira vho vhulaiwaho kha nndwa dza lifhasi dzothe dzo tanganal

$<<$ Maswole a vhunyunyu a ita khuwa! $>>$

$<<$ Zwifanyiso zwa mutevhe wa vhunyunyu ho ita mufolo zwi khou leleda muyani $>>$

Lunyunyu lutuku: Mulangammbi, izwo ro tou zwi itisa hani?

Mulangammbi: I rai ndi u vhudze. Musi ndi saathu $\mathrm{u}$ kudzela makumba, ndi todi u la mahinyahinya nda fura. Mahinyahinya ane nda a funesa ndi malofha a muthu. Zwino ndi fhufha nda ya kha muthu - kanzhi o edelaho. 
Jr.: Then what do you do?

G: I stick my pointy snout, and [SLURPP!!] suck up blood.

Jr.: Oh, you suck their blood and they die?

G.: No! Taking a little blood doesn't kill them.

Jr.: So what makes you deadly?

G.: When I bite them, I also leave a little "gift." If last week I drank blood from someone with malaria, then this week I leave some malaria behind. Aren't I nice?!

Jr.: I see. So our mosquito army spreads malaria. How fun! What happens next?

G.: When I am done feeding, I am so full that I turn red. Do you know why?

Jr.: You must be full of people blood!

G.: That is right. I am so full, I fly to the wall and rest. A few minutes later, I am on my way to spread even more malaria.

Jr.: And what happens to the person you bit?

G.: Well, the malaria bugs I left start to multiply. Soon, that poor human has billions of malaria bugs living inside. It is like having a whole city full of tenants, but they do not pay rent! They just give that poor human malaria!

Jr.: What is malaria?

G.: They get a high fever and usually a terrible headache. Best of all, sometimes they throw up! I love being a mosquito!

Jr.: Sounds great! Where do we start?
LL.: Nga murahu ha izwo vha ita mini?

MM: Ndi toka ludomo lwanga holwu lwa lutoswi, nda [slllp!] tzonzwa, malofha.

LL: Oh, vha tzonzwa malofha avho vha fa?

MM: Na khathihi! U dzhia zwidofha nyana khavho a zwi vha vhulahi.

LL: Zwino ndi zwifhio zwine zwa ita uri vha vhe khombo?

MM: Musi ndo luma, ndi vha siela kufhiwa kutuku. Arali vhege yo fhiraho ndo nwa malofha kha muthu are na dali zwi amba uri ino vhege muthu ane nda mu luma ndi mu sia na dali. Ndi a vhavha thi?!

Jr: Ndi a vhona. Zwi amba uri mmbi yashu ya vhunyunyu i phadaladza dali. Ndi zwavhudi hezwo! Zwino hu itea mini nga murahu ha izwo?

MM: Musi ndo no fhedza u la, ndi vha ndo fura nga maanda lune ndi a tswukuluwa. $U$ a divha uri ndi nga mini?

LL: Vha fanela $u$ vha vho dala nga malofha a vhathu!

MM: Ndi ngoho heyo. Ndi vha ndo fura lune u a divha, ndi tea u fhufha nda ya luvhondoni nda tou thoma nda awela. Nga murahu ha miminete I si gathi, ndi a takutshedza nda yo phadaladza dali hafhu nga vhunzhi.

LL: Zwino hu itea mini kha muthu we vha mu luma?

MM: Khezwi, zwitzhili zwa dali zwe nda sia zwi thoma u beba zwa anda. Hu si kale ula muthu wa vhathu u vha a na zwinzhizwinzhi, zwi sa vhalei zwi tshi khou tshila ngomu khae. Zwi di tou fana na dorobo yo dala nga mabodasi hone a sa badeli rennde! A sokou tou nea muthu wa vhathu dali!

\section{LL: Dali ndi mini?}

MM: Ndi musi a tshi vha na mufhiso wa muvhili ure ntha kanzhi na thoho I remaho lu shushano. Zwi no takadzesa ndi uri tshinwe tshifhinga vha a ita na $u$ tanza. Ndi a zwi funa $u$ vha lunyunyu.

LL: Zwi pfala zwi zwithu zwa nthesa! Naa ri thoma gai? 
$<<$ If convenient, General points to a chart with the name of the village. $>>$

G.: We are going to attack $<<$ VILLAGE NAME $>>$.

Announcer: In this village lives Tshinakaho and her child, Mulalo. Tshinakaho loves her child dearly, and she wants Mulalo to stay safe from malaria.

[Scout \#1 flies in]

Scout \#1: Bad news, General. Tshinakaho has agreed to spray the walls of her house with pesticides.

Junior: Why is that a problem?

General: I said how after we eat we have to fly to the wall and rest. When the walls have poison, we won't ever take off! If this spraying becomes popular, $<<$ VILLAGE NAME $>>$ will be almost completely safe from me and my army.

[Scout \#2 returns]

Scout \#2: An update from Mulalo, General.

$<<$ Shows image of Mulalo $>>$ Mulalo said, "I am worried the spray will get on my doll and make her sick!"

General: That is great news! Keep it up, Mulalo! Without the spray, it is far easier for me to give malaria to lots of Tshinakaho's family. A few weeks later, and my army can give malaria to even more of the village!

Junior: Mosquitos Rule! But how will we get the whole village sick? Won't the neighbors have spray on their walls?
$<<$ Arali zwi tshi konadzea, Mulangammbi u sumba dzina la muvhundu kha tshathi ire luvhondoni. $>>$

MM: Ri khou ya u thasela $<<$ DZINA L LA

MUVHUNDU $>$.

Mudivhadzi: Kha hoyu muvhundu, hu dzula vhoTshinakaho na nwana wavho Mulalo. VhoTshinakaho vha funesa nwana wavho nahone vha toda Mulalo a tshi dzula o tsireledzea kha dali.

[Matshingilane \#1 tshi dzhena tshi tshi fhufha]

Matshingilane \#1: Mulangammbi, mafhungo mavhi khea. Tshinakaho o tenda uri hu fafadzelwe mbondo dza nndu yawe nga tshivhulayazwikhokhonono.

\section{LL: Izwo zwi thaidzo nga mini?}

MM: Ndo talutshedza uri hani ro fhedza u la ra fhufhela luvhondoni ra ya ra awela. Musi mbondo dzi na phoizeni (vhutulu/mushonga), a ri nga dovhi ra kona u takuwa. Arali hoyu mufafadzelo wa tou divhea, muvhundu wothe $<<$ DZINA LA MUVHUNDU $>>\mathrm{u}$ do vha wo tsireledzea kha nne na mmbi yanga.

[Matshingilane \#2 u a vhuya]

Matshingilane \#2: Manwe maswa maswa khea a bvaho kha Mulalo, Mulangammbi.

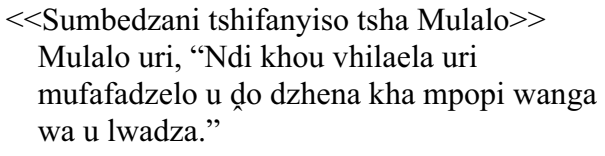

MM: Hee, hao ndi mafhungo a vhudisa! Isai phanda nga uralo Mulalo! Arali hu si na mufafadzelo, zwi a nndelutshela u phadaladza dali kha vhathu vha muta wa vho-Tshinakaho nga vhunzhi. Nga murahu ha vhege dzi si gathi, mmbi yanga I nga kona $u$ phadaladza dali kha vhathu vhanzhi vha muvhundu hoyu.

LL: Rine vhunyunyu ri dzingwena! Zwino ri do tou zwi itisa hani uri ri lwadze muvhundu wothe? Naa vhadzulatsini vhavho a vha na mushonga kha dzimbondo? 
General: If we can attack even one family, the rest of the village is easier. We mosquitos will stay filled up with fresh malaria bugs, and when the other villagers are away from home, the spray on their home's walls cannot protect them.

Junior: I see. Then we can bite them!

General: That is right. It takes a village to fight us. Everyone needs to spray their houses. Otherwise, we will win!

\section{The village}

[Tshinakaho and Mulalo (child) sitting in front of their home. Mulalo is busy playing on the floor with her toys. This side contains some food, a water container, a table, a bowl with water and a cleaning cloth, toys and other props needed. There is a door or something representing a door to outside the home.]

Tshinakaho: The rains have come. Soon and army of mosquitos will be here. I need to do something!

General, in a magnified corner of the room/other side of the stage: "I have to do something about Tshinakaho. Junior, carry this message to Mulalo."

$$
<<\text { General sends Junior to whisper in M's }
$$
ear $>>$

M: Mummy, please don't let them come to spray our house again. The spray will hurt my doll.

$<<$ General is dancing with joy! $>>$ "Mulalo is the best! Good work!"

Tshinakaho: If we do not spray, we are all at risk of getting sick. Good parents do not let mosquitoes into their homes.

$$
<<\text { General is sad. }>>
$$

M: I understand, mommy, but malaria control sprays all over our house and even my room. I worry that whatever kills mosquitoes is bad for my doll and
MM: Arali ra nga kona u thasela muvhundu wothe, na $\mathrm{u}$ thasela muvhundu wothe zwo ri lelutshela. Rine vhunyunyu ri do dzula ro fura zwitzhili, nahone vhanwe vhadzulapo vha vhuya vha tou bva nnda ha mudi wavho, mushonga u re kha dzimbondo dza midini yavho a I nga koni u vha tsireledza.

LL: Ndi khou vha wana zwino. Zwi amba uri rine ri nga konaha $u$ vha luma.

MM: Ndi zwone. U lwa na rine, zwi toda muvhundu wothe. Vhothe vha fanela u fafadzela nndu dzavho.

Zwa sa ralo rine ri a vha phala.

\section{Muvhunduni}

[Vho-Tshinakaho na Mulalo (n்ana) vha khou amba vho dzula phanda ha mudi wavho. Mulalo u kati u khou tambisa dzithoyi dzawe. Kha holwu lurumbu, huna zwiliwa, tshigubu tsha madi, tafula, ndishi ire na madi na labi la u koropa, thoyi na zwinwe zwishumiswa zwa litambwa. Huna vothi lo imelaho vothi la u bvela nnda ha mudi.]

Vho-Tshinakaho: Dzimvula dzo no thoma khedzi. $\mathrm{Hu}$ si kale mmbi ya vhunyunyu I do vha yo shoma. Ndi tea $\mathrm{u}$ vhamba maano.

Mulangammbi vha kha inwe khona I vhonalaho ya lufhera/lunwe lurumbu lwa vhugalatenga. Ndi tea u ita zwinwe zwithu.

$<<$ Mulangammbi vha ruma Lunyunyana $\mathrm{u}$ hevhedza ndevheni ya Mulalo>>

M: Mma, vha songo tenda vha tshi da u fafadzelwa nndu yashu hafhu. Mufafadzelo u do vhaisa mpopi wanga.

$<<$ Mulangammbi vha khou tshina nga dakalo! $>>$ Mulalo, ndi wa nthesa. Wo shuma zwavhudi!

Tshinakaho: Arali ra sa fafadzelelwa, rothe ri khomboni ya u lwala. Vhabebi vhavhudi a vha tendeli vhunyunyu mahayani avho.

$<<$ Mulangammbi vho tungufhala $>>$

Mulalo: ndi pfesesa mma, fhedzi vha mufafadzelo vha fafadzelwa hothe hothe nduni yashu na kamarani yanga. Ndi a vhilaela uri zwi no vhulahi vhunyunyu a 
Bobby (the dog?)... and for me too!

T: But we can do things to keep us safe from the spray. We can keep the spray from getting into our food and water by covering the containers tightly and moving them several meters away from our house. We also need to move our dishes and pots.

M: But what about my toys and my bed? I don't want spray on my toys!

$<<$ The General dances with joy again! $>>$

Announcer: Now what do you think we should do? (ask school children)

$\mathrm{M}$ [thinking]: I can just move my bedding and toys out of the house near the food and water, a few meters outside the house. Then the bedding and toys won't get spray on them.

$<<\mathrm{T}$ and Mashudu carry bedding and toys outside. $>>$

M: What about Bobby?

Announcer: Ask children-what do you think they should do with Bobby?

T: Yes, we should move him and all the other animals away from the spray and make sure they stay away.

\section{$<<$ General is sad again. $>>$}

General: Junior, bring one more message for our friend $\mathrm{M}$.

$$
<<\text { Junior flies to M's ear. }>>
$$

M: But what about the things we can't move?

T: You have a beautiful school bag. When it rains, do your books get soaking wet?

M: No, they don't because I cover my school bag with my raincoat.

T: So, the same idea works... just like you use your raincoat to cover your school bag, we have to cover those things we can't move. Now you can help me get ready! si zwavhudi na kha mpopi wanga na mmbwa yanga Bobby, na nne!

T: Fhedzi hu na zwine ra nga ita $u$ u di tsireledza kha mufafadzelo. Ri nga thivhela uri mufafadzelo u sa dzhena zwiliwani na mdini ashu nga u tiba ra khwathisa zwo faraho izwo zwithu nahone ra zwi bvisela nnda ra zwi vhea kule na nndu nga mimithara yo vhalaho. Ri tea u bvisa na dzindishi dzashu na dzibodo.

M: A thi todi mufafadzelo kha dzithoyi dzanga!

$<<$ Mulangammbi vha tshina vho takala hafhu! $>>$

Mudivhadzi: Zwino ni humbula uri ri tea $u$ ita mini?(Vhudzisani vhana vha tshikolo)

M: [a tshi khou humbula]: Ndi nga kona u bvisa nguvho dzanga na thoyi dzanga nduni, nda dzi vhea tsini na zwiliwa na madi, kule ha nndu nga mimithara I si gathi. Nguvho na thoyi a zwi nga vhi na mufafadzelo khazwo.

$<<$ Tshinakaho na Mulalo vha hwalela nguvho na thoyi vha isa nnda. $>>$

Mulalo: Bobby tshone?

Mudivhadzi: Vhudzisani vhana vha tshikolo - Zwino ni humbula uri ri tea u ita mini nga Bobby?

Tshinakaho: Ee, ri tea u tshi bvisa, na zwinwe zwifuwo zwothe ra zwi bvisela kule na mufafadzelo ra ita uri zwi bvele kule.

$<<$ MM vho dovha vha tungufhala. $>>$

MM: Lunyunyu Lutuku, isai munwe mulaedza kha khonani yashu Mulalo.

$<<$ LL u fhufha a ya ndevheni ya Mulalo. $>>$

Mulalo: Zwino zwithu zwinw ra sa kone u zwi bvisa?

Tshinakaho: Ni na mukhwama wa u naka. Musi mvula I tshi na, bugu dzanu dzi a nukala?

M: Hai, a dzi nukali ngauri ndi fukedza mukhwama wanga nga renikhouthu.

T: Muhumbulo wonoyo muthihi u a shumavho hanefha....sa zwine na ita ni tshi tibedza mukhwama wanu nga renikhouthu, ri tea u tibedza hezwo zwithu zwine ra sa kone $u$ zei bvisa. Zwino ni nga nthusa $u$ 
$<<$ Here, and in all following cases of advice,

Tshinakaho performs safe behaviors. $>>$

$<<$ General is sad: "Oh no, Tshinakaho is giving good advice and doing the right thing. $>>$

M: that makes sense to get ready for the sprayers. So mommy, when the sprayers arrive, can I stay in the house and watch TV?

T: No Mulalo, it is important to stay out of the house until all the spraying is done. The house will get all wet with that spray! We will have to wait outside of the house at least an hour before going back in after the spray team leaves. We need to give the spray a chance to dry.

$<<$ General is sad, pacing: "I don't like to hear this." Send Junior over again. >>

M: But then when we go into the house mommy, won't there still be spray everywhere we eat and play?

T: The spray team will give us a plastic sheet to cover our table before they spray. It will keep the spray off our table just like your raincoat keeps the rain off of you. When they are finished, they will remove the sheet. And after they leave, I will bathe our table- just like you bathe yourself. I will wipe our table with soapy damp cloth.

$<<$ General perks up, calls to Junior: "Wash the walls! Tell them to wash the walls!" >>

M: Mommy, will you wash the walls too?

T: No, we must not wash the walls! We need the spray there to keep the mosquitoes away...

$<<$ General appears crushed: "Nooooo! >>

$\mathrm{T}$ : ... but we will wash the tables and any other furniture left behind very well.

M: But Mommy, now the spray will be in the cleaning water and on the cleaning cloth!

T: Clever girl. That is why I should discard the water away from the home and throw away the cloth. dilugisa!

$<<$ Hafha na fhethu hothe hu tevhelaho, vho-

Tshinakaho vha ita magao tsireledzeaho. $>>$

$<<$ Mulangammbi vho tungufhala: Vho-tshinakaho vha khou nea tsivhudzo dzavhudi nahone vha khou ita zwone $>>$

Mulalo: Zwi a pfesesea u lugisela vha mufafadzelo. Zwino mma, vha mufafadzelo vha tshi swika, ndi nga dzula nduni nda vhona TV?

T: hai Mulalo, ndi zwa ndeme uri ri dzlule nnda ha nndu u swika musi u fafadzelwa ho no fhela. Nndu I do nukala yothe nga mufafadzelo! Ri do tea u lindela ri nnda ha nndu lwa awara nthi ri saathu u vhuyelela nduni nga murahu ha musi vho no fafadzela. Ri tea $u$ tendela mufafadzelo wa thoma wa oma.

$<<$ Mulangammbi vho tungufhala, vha tshi tsa vha tshi gonya. A thi funi u pfa hezwi" Rumelani LL hafhu. $>>$

Mulalo: Mara mma, musi ri tshi vhuyelela nduni, hu do vha si tshee na mufafadzelo hothe hune ra lela hone na hune ra tambala hone?

Tshinakaho: Vha tshigwda tsha mufafadzelo vha do ri fha mapulasitiki uri ri tibedze tafula musi vha saathu $\mathrm{u}$ fafadzelwa. Li do ita uri mufafadzelo u sa wele kha tafula yashu sa zwine renikhouthu ya thivhela mvula kha inwi. Musi vho no fhedza, vha do bvisa pulasitiki. Nne ndi so phumula tafula nga labi lo nukalaho li re na tshisibe.

$<<$ Mulangammbi vha imisa thoho vha vhidelela LL. "Tanzwani mbondo! Vha vhudzei vha tanzwe mbondo!">>

Mulalo: Vha do tanzwa na mbondo?

T: Hai, a ri tei u tanzwa mbondo! Ri toda mufafadzelo $\mathrm{u}$ thatha vhunyunyu....

$<<$ MM vha vhonala vho pwashekana: Haaaiiiii! $>>$

$\mathrm{T}$ : ...fhedzi ri do tanzwa mbondo na inwe fanitshara yo salaho zwavhudi.

Mulalo: Fhedzi Mma, musi zwino mufafadzelo u do vha u madini a u kulumaga na kha labi!

T: Musidzana wa u thanya. Ngazwo ndi tshi tea $\mathrm{u}$ tevhula madi kule na hayani, nda lata na labi la hone. 
M: But what about spray on the floor where I play?

T: Mommy already knows how to clean the floor. I will sweep it. There will probably be many dead cockroaches, mosquitoes, and insects form all the spray.

$<<$ General is sad. Holds his head and weeps loudly. $>>$

M: Oh goody! Our chickens will have a feast!

$<<$ General is sad. Weeps even more loudly and dramatically. $>>$

T: No, not this time, Mulalo. Remember all dead cockroaches, mosquitoes and other insects will have spray on them. We don't want the chickens to get that spray inside their bodies, because we don't want to taste in in their eggs or meat.

M: So what will you do with them, Mommy?

T: I will bury them, burn them, or toss them into the latrine...

$$
<<\text { General: "Not the latrine!!!!" }>>
$$

T:...I will also wash the floors that I can with soap and water. Make sure you don't come close to that while I sweep or wash. Better you should play outside.

\section{$<<\mathrm{T}$ sweeps floor and carries what she has swept offstage $>>$}

M: Mommy is so clever. I do not want our chickens and Bobby to eat bugs covered in the spray! And I don't want to be near either!

$\mathrm{T}$ : Then, guess what is then left for mommy to do? [T holds up her hands]

$\mathrm{M}$ [pauses, thinking]: You have to wash your hands!

T: Yes! I will use soap and water to make sure no spray is on my hands.

$<<$ T wash hands with soap and a basin (if feasible to wash on stage). $>>$

M: Now I understand, mosquitoes are too dangerous.
Mulalo: Fhedzi uyu mufafadzelo u re afha fhasi hune nda tamba hone?

T: Mma vha divha uri vha kulumagise hani fuloro. Ndi do u swiela. Hu nga vha hu na mabete manzhi, vhunyunyu na zwinwe zwikhonono zwo faho nga nthani ha mufafadzelo.

$<<\mathrm{MM}$ vho tungufhala. Vha farelela thoho vha zhamba. $>>$

Mulalo: Oh, ndi zwavhudi. Khuhu dzashu dzi do tou diphina!

$<<$ MM vho tungufhala. Vha tou nana u zhamba. $>>$

T: Hai, I sini hezwino Mulalo. Ni humbule uri mabete othe o faho, vhunyunyu hothe na zwinwe zwikhokhonono zwo faho zwi do vha zwi na mufafadzelo khazwo. A ri todi khuhu dzi tshi vha na mufafadzelo mmivhilini yadzo ngauri a ri todi u zwi la kha makumba adzo na nama yadzo.

Mulalo: Zwino vha do ita ngazwo Mma?

T: ndi do zwi gwela dindini, u zi fhisa kana nda zwi lata thoilethe.

$<<$ MM: I si ni thoilethe!!!! >>

T: ...Ndi do koropa fuloro dzine nda kona nga madi na tshisibe. Ni thogomele uri ni songo sendela tsini musi ndi tshi khou swiela kana u koropa. Ndi khwine ni tshi vha ni tshi khou tamba nnda.

$<<\mathrm{T}$ vha swiela fuloro vha bvisela mathukhwi nnda ha vhugalatenga $>>$

Mulalo: Mma vho thanya wee. A thi todi khuhu dzashu na Bobby dzi tshi la zwikhokhonono zwo dalaho mufafadzelo. Na nne a thi todi vha tsini!

T: Zwino humbulani uri tsho salelaho Mma uri vha tshi ite ndi mini? [T u takulela ntha zwanda zwawe]

Mulalo [U ima, a humbula]: Vha tea u tamba zwanda!

T: Ee. Ndi do shumisa tshisibe na madi u itela uri ndi vha na vhutanzi uri a huna mufafadzelo kha zwanda zwanga.

$<<$ T vha tamba zwanda nga tshisibe na madi ndishini kha vhugalatenga (arali zwi tshi konadzea).>>

Mulalo: Zwino ndi a pfesesa, vhunyunyu vhu khombo 
You are the best mommy and I am not scared of the malaria spray workers anymore.

$<<$ General is the saddest of all $>>$ AARgh!!!

$<<$ For the rest of this scene, the General is miming increasingly frantic frustration, pounding the walls, pulling his or her hair, throwing things, tipping over the headquarters table, ripping down the chart with village name, sobbing hysterically, falling face down and pounding the floor, etc. There is no limit to how melodramatic the General can act... >>

While general makes a scene move stuff back into the house.

T: Let's see if you can remember what I have taught you. How can you help mommy to prepare for spraying?

$<<\mathrm{M}$ points to food, water and cooking utensils. $>>$

M: I can help you to cover food, water and cooking utensils tightly and move them outside the home.

T: And what about your toys and bedding?

M: I will help you to move my toys, Mupopi, Bedding and Bobby outside as well.

T: And what should we all do while they are busy spraying?

M: We should all stay far away from the house.

T: Ask the school children-How long before we can go back in again? [wait for the children to answer]

M: At least one hour before mommy can go back in to sweep and wash the floor and wipe the table with a damp cloth!

$$
<<\text { T holds up a broom and cloth }>>
$$

T: You are a clever girl!

M: I am going to teach Granny and Mpho's mother as well. I do not want spray to get on their things either. nga maanda. Vha mme wa khwinesa nahone a thi tsha ofha vha mufafadzelo wa dali.

$$
<<\text { MM vho tungufhalesa }>>\text { AARgh!!! }
$$

$<<$ Hafha hothe, MM vha sumbedza tsumbo dza u dzikukana, vha rwa mbondo, vha di kokodzekanya mavhudzi, vha latekanya zwithu, vha thudzekanya tafula ya gammbani, vha kherukanya dzitshati dza madzina a muvhundu vha tshi khou tswimila, vha wa vha lala fhasi nga khofheni na u ginda fhasi nz. A huna $u$ thivhelwa kha tshikalo tsha u dzikukana ha MM hune vha nga hu sumbedza... >>

Musi MM vha tshi khou ita misumbedzo, vhuyedzedzani thundu nduni

$\mathrm{T}$ : Zwino kha ri vhone arali ni tshi kha di humbula zwe nda ni funza. Ni nga thusa hani Mma u lugisela vha jufafadzelo?

$<<$ Mulalo u sumba zwiliwa, madi na thundu ya $\mathrm{u}$ bika. $>>$

Mulalo: Ndi nga vha thusa nga u tiba zwiliwa, madi na pani dza u bika nda tou khwathisa nda bvisela na thundu nnda ha haya.

\section{T: Thoyi na dzinguvho dzone?}

Mulalo: Ndi do vha thusa u bvisa dzithoyi, Mupopi, nguvho na Bobby na tshone nda tshi bvisela nnda.

T: Rine ri fanela $u$ ita mini musi vha kati na $u$ fafadzela>

Mulalo: Ri tea u vha ri kuuule na nndu.

T: Vhudzisani vhana - Ri tea u lindela tshifhinga tshingafhani ri saathu u vhyelela nga ngomu nduni? [Lindelani vhana vha fhindule]

Mulalo: Awara nthihi musi mma vha tshi nga vhuyelela nduni u swiela na $u$ koropa fhasi na $u$ phumula tafula nga labi lo nukalaho.

$<<$ T vha takulelal ntha luswielo na labi $>>$

$\mathrm{T}$ : Ni musidzana o thanyaho!

Mulalo: Ndi do funza-vho na gugu na mme a Mpho. A thi todi mufafadzelo u tshi dzhena kha thundu dzavho. 
T: We can all work together to stay safe!

\section{Mosquito attack in the village.}

$<<$ Flying mosquitoes in military formation

approaching Tshinakaho's village $>>$

Scout: the entire village has listened to Tshinakaho. They are all spraying.

$<<$ Dozens of attacking and dying
mosquitoes: $>>$

Mosquito 1: What is this?

Mosquito 2: Oh no, it is poison!

Mosquito 1, 2, 3...: AAAargh!!

$<<$ Mosquitoes are dying dramatic deaths. Make the deaths big, loud, exaggerated, and silly. Spin around, holding own neck. Fall on ground and kick feet. Pause, then kick one last time, etc. $>>$

\section{Mosquito headquarters:}

Junior, stumbling back: General, all the mosquito soldiers you sent to spread malaria are gone!

General: The battle is over. For the first time, we have lost! Who would have thought a mother and her daughter could defeat my beautiful army of death and disease!

$$
<<\text { Image of happy villagers }>>
$$

Junior, all battered up [wearing bandages or a sling, if feasible]: So have the mosquitoes lost our war against humans?

General, bandaged and limping into the sunset, with only Junior by his side: In six months, the spray will wear off. If the humans forget to spray again, mosquitoes and malaria will win next time! This war is not over yet...
T: Ri nga shumisana rothe uri ri tsireledzee!

\section{Vhunyunyu vhu thasela muvhundu.}

$<<$ Vhunyunyu vhu no khou fhufha ho ita guma la mmbi ya maswole u swika muvhunduni wa vho Tshiakaho $>>$

Muvhundu wothe wo thetshelesa vho Tshinakaho. Vhothe vha khou fafadzelelwa.

$<<$ Guma la vhunyunyu li thaselaho line la khou ita na u fa: $>>$

Lunyunyu 1: Ndi mini izwi?

Lunynyu 2: Ehe Hai, ndi mushonga!

Lunyunyu 1, 2, 3...AAAargh!!

$<<$ Vhunyu vhu fa nga ndila I mangadzaho. Itani uri mpfu dza hone dzi vhonale dzi khulwane, dzi na phoso, zwo titilidzwa nahone zwi tshi seisa.

Dzunguluwani, no farelela mukulo wanu. Niu we ni raherahe. Ni awele nyana ni kone $u$ raha lwa u fhedzisa, nz $>>$

\section{Gammbani ya vhunyunyu}

LL a tshi khou pepeleka a tshi vhuya: VhoMulangammbi, maswole othe a vhunyunu e vha a rumela u phadaladza dali ha tsheeho!

MM: Heyi nndwa o fhela. Lwa u tou thoma, ro kundwa. Ndi nnyi we a vha a tshi nga humbula uri murathu na mukomana vha nga kunda mmbi yanga ya vhudivhudi ya bulayo na malwadze!

$<<$ Hu vhonala vhathu vha muvhunduni vho takala. $>>$

LL, o huvhala, [o banditshiwa kana o vhhofhiwa tshanda arali zwi tshi konadzea]: Zwi amba uri vhathu vho ri kunda?

MM, vho banditshiwa nahone vha tshi khou tudza, vha tshi ya thango ya vhukavhela, vha tshi tou vha na LL nga thungo yavho. Nga murahu ha minwedzi ya rathi, mufafadzelo u do vha wo fhufha. Arali vhathu vha hangwa u fafadzela hafhu, vhunyunyu na dali zwi do wina roundu I daho. Heyi nndwa a yo ngo fhela.... 
- The script can also be used as a play or puppet show.

- With illustrations, it can be made into a picture book.

- You can increase the number of lessons in discussion. For example, get people to talk about why they don't want to spray. For example:

- Believe spraying will bring cockroaches to their homes (remind them that there will likely be dead cockroaches as a result of spraying to address this concern.

○ Spray gives them headaches. That is why they need to stay far away and not go back for 1-2 hours.

- Spraying might even increase the numbers of mosquitoes. Explain that mosquitoes do not thrive on spray.

- Spray workers might see what is in their homes and spread stories in the village or even 'steal' their things.

- You can use the characters to reiterate the points in discussion. For example, one of the actors introduce one way to prevent malaria, e.g., bednets; you can have them teaching yet another character like a husband or child e.g., to make sure yard is clean from standing water, etc.

- You can have a role-play where the actors ask questions or play a scenario and participants must say if the actor did what was correct based on what they learned.

- We can give out a pre - post questionnaire to accesss learning

- At the end you can give them a check sheet or pamphlet.

- If you present to children, can we give the child a sticker if they help their parent on one of the things on the check sheet. Perhaps at church or school?

Melodramatic sadness video for inspiration for General's tragic ending: https://www.youtube.com/watch?v=TrYxFEOQCpg 


\section{Appendix 3: The song sung by VHEMBE staff in TshiVenda after the presentation of the skit}

A sample clip from the song performance can be found at https://www.youtube.com/watch?v=S_gbrBxDGys

\begin{tabular}{|c|c|}
\hline Tsini ha lunyunyu & Near the mosquito \\
\hline Tsini ha lunyunyu; & Near the mosquito \\
\hline Tsini halwo & Near it \\
\hline Ni songo sendela tsini halwo. & Do not go near it. \\
\hline Arali no edela, di tsireledzeni & If sleeping, protect yourself. \\
\hline Lwa ni luma ni do lwala malaria. & If it bites you, you will have malaria. \\
\hline Chorus: Ditsereledzeni x3 & Chorus: Protect yourself $\mathrm{x} 3$ \\
\hline Kha mufafadzelo. & From malaria control indoor spraying \\
\hline Rapping/ Talking: & Rapping/ Talking: \\
\hline Tsumbo dza malaria & Signs and symptoms of malaria: \\
\hline Mufhiso ure ntha & High fever \\
\hline U rema ha thoho & Headache \\
\hline $\mathrm{U}$ tanza & Vomiting \\
\hline $\mathrm{Na} u$ tetemela & Shivering \\
\hline Vha tshi pfa izwo, kha vha ye kiliniki. & If you feel these, please go to the clinic. \\
\hline Musi vha mufafadzelo vha tshi da; & When the spray workers come; \\
\hline Tendani vha tshi ni fafadzelela. & Allow them to spray \\
\hline Hone tevhedzani ndaela dzavho; & However, follow their instructions; \\
\hline Uri na inwi-vho ni tsireledzee. & So that you can also be protected. \\
\hline Chorus: Ditsereledzeni x3 & Chorus: Protect yourself $\mathrm{x} 3$ \\
\hline Kha mufafadzelo. & From malaria control indoor spraying \\
\hline Rapping/ Talking: & Rapping/ Talking: \\
\hline Tibani zwiliwa, tibani madi & Cover the food, cover the water \\
\hline Vheani fanitshara vhukati ha nndu, & Push the furniture to the middle of the house \\
\hline $\begin{array}{l}\text { Zwi no takulea, bviselani nnda ha nndu, } \\
\text { Inwi na vhana, ni bvele kule. }\end{array}$ & Move what is portable outside the house, \\
\hline Mulaedza khoyo. & Here is the message. \\
\hline Vho u pfana? & Did you hear it? \\
\hline Ndi zwa ndeme u thivhela malaria & It is important to prevent malaria. But; \\
\hline Chorus: & Chorus: \\
\hline
\end{tabular}

Received: 22 December 2018 Accepted: 4 June 2019

Published online: 14 June 2019

\section{References}

1. WHO. World malaria report. Geneva: World Health Organization; 2018.

2. Moonasar D, Nuthulaganti T, Kruger PS, Mabuza A, Rasiswi ES, Benson FG, et al. Malaria control in South Africa 2000-2010: beyond MDG6. Malar J. 2012:11:294

3. Raman J, Morris N, Frean J, Brooke B, Blumberg L, Kruger P, et al. Reviewing South Africa's malaria elimination strategy (2012-2018): progress, challenges and priorities. Malar J. 2016;15:438.

4. Elimination 8 Regional Initiative. Elimination 8 strategy: acceleration plan 2018-2020. Windhoek, Namibia; 2018

5. Bouwman H, Sereda B, Meinhardt HM. Simultaneous presence of DDT and pyrethroid residues in human breast milk from a malaria endemic area in South Africa. Environ Pollut. 2006;144:902-17.
6. Longnecker MP. Why DDT matters now. Am J Epidemiol. 2005;162:726-8.

7. Wolff MS, Zeleniuch-Jacquotte A, Dubin N, Toniolo P. Risk of breast cancer and organochlorine exposure. Cancer Epidemiol Biomark Prev. 2000;9:271-7.

8. U.S $>$ Department of Health and Human Services. Toxicological profile for DDT, DDE, and DDD. Agency for Toxic Substances and Disease Registry; 2002.

9. Hlongwana KW, Mavundza EJ, Mohapi EP, Kruger P, Urbach J, Mukaratirwa $S$, et al. Vector-control personnel's knowledge, perceptions and practices towards insecticides used for indoor residual spraying in Limpopo Province, South Africa. Parasit Vectors. 2013:6:118.

10. Eriksson P, Ahlbom J, Fredriksson A. Exposure to DDT during a defined period in neonatal life induces permanent changes in brain muscarinic receptors and behaviour in adult mice. Brain Res. 1992;582:277-81.

11. Malik JK, Aggarwal M, Kalpana S, Gupta RC. Chlorinated hydrocarbons and pyrethrins/pyrethroids. In: Gupta RC, editor. Reproductive and developmental toxicology. 2nd ed. Saint Louis: Elsevier Science; 2017. p. 633-55. 
12. Patisaul HB, Adewale HB. Long-term effects of environmental endocrine disruptors on reproductive physiology and behavior. Front Behav Neurosci. 2009;3:10.

13. Ben Slima A, Chtourou Y, Barkallah M, Fetoui H, Boudawara T, Gdoura R. Endocrine disrupting potential and reproductive dysfunction in male mice exposed to deltamethrin. Hum Exp Toxicol. 2017;36:218-26.

14. Mandhane SN, Chopde CT. Neurobehavioral effects of low level fenvalerate exposure in mice. Indian J Exp Biol. 1997;35:623-7.

15. Nasuti C, Cantalamessa F, Falcioni G, Gabbianelli R. Different effects of type I and type II pyrethroids on erythrocyte plasma membrane properties and enzymatic activity in rats. Toxicology. 2003;191:233-44.

16. Murray J, Eskenazi B, Bornman R, Gaspar FW, Crause M, Obida M, et al. Exposure to DDT and hypertensive disorders of pregnancy among South African women from an indoor residual spraying region: the VHEMBE study. Environ Res. 2018;162:49-54.

17. Huang J, Eskenazi B, Bornman R, Rauch S, Chevrier J. Maternal peripartum serum DDT/E and urinary pyrethroid metabolite concentrations and child infections at 2 years in the VHEMBE birth cohort. Environ Health Perspect. 2018;126:067006.

18. Chevrier J, Rauch S, Crause M, Obida M, Gaspar F, Bornman R, et al. Associations of maternal exposure to dichlorodiphenyltrichloroethane and pyrethroids with birth outcomes among participants in the Venda health examination of mothers, babies and their environment residing in an area sprayed for malaria control. Am J Epidemiol. 2019;188:130-40.

19. Coker E, Chevrier J, Rauch S, Bradman A, Obida M, Crause M, et al. Association between prenatal exposure to multiple insecticides and child body weight and body composition in the VHEMBE South African birth cohort. Environ Int. 2018;113:122-32.

20. Eskenazi B, An S, Rauch SA, Coker ES, Maphula A, Obida M, et al. Prenatal exposure to DDT and pyrethroids for malaria control and child neurodevelopment: the VHEMBE cohort, South Africa. Environ Health Perspect. 2018;126:047004.

21. Republic of South Africa malaria elimination strategic plan 2012-2018. South Africa National Department of Health: Pretoria; 2012.

22. Cox SN, Guidera KE, Simon MJ, Nonyane BAS, Brieger W, Bornman MS, et al. Interactive malaria education intervention and its effect on community participant knowledge: the malaria awareness program in Vhembe district, Limpopo, South Africa. Int Q Community Health Educ. 2018;38:147-58.

23. Kroeger A, Meyer R, Mancheno M, Gonzalez M. Health education for community-based malaria control: an intervention study in Ecuador, Colombia and Nicaragua. Trop Med Int Health. 1996;1:836-46.

24. Marsh VM, Mutemi W, Some ES, Haaland A, Snow RW. Evaluating the community education programme of an insecticide-treated bed net trial on the Kenyan coast. Health Policy Plan. 1996;11:280-91.

25. Nkuo Akenji TK, Ntonifor NN, Ching JK, Kimbi HK, Ndamukong KN, Anong DN, et al. Evaluating a malaria intervention strategy using knowledge, practices and coverage surveys in rural Bolifamba, southwest Cameroon. Trans R Soc Trop Med Hyg. 2005;99:325-32.

26. Rhee M, Sissoko M, Perry S, McFarland W, Parsonnet J, Doumbo O. Use of insecticide-treated nets (ITNs) following a malaria education intervention in Piron, Mali: a control trial with systematic allocation of households. Malar J. 2005:4:35

27. Ayi I, Nonaka D, Adjovu JK, Hanafusa S, Jimba M, Bosompem KM, et al. School-based participatory health education for malaria control in Ghana: engaging children as health messengers. Malar J. 2010;9:98.

28. Ghosh SK, Patil RR, Tiwari S, Dash AP. A community-based health education programme for bio-environmental control of malaria through folk theatre (Kalajatha) in rural India. Malar J. 2006;5:123.

29. Lim R, Tripura R, Peto TJ, Sareth M, Sanann N, Davoeung C, et al. Drama as a community engagement strategy for malaria in rural Cambodia. Wellcome Open Res. 2017;2:95.
30. World Health Organization. Indoor residual spraying: an operational manual for indoor residual spraying (IRS) for malaria transmission control and elimination. Geneva: World Health Organization; 2015. ISBN 978-92-4-150894-0.

31. Chandonait P. President's malaria initiative BMP manual best management practices (BMP) for indoor residual spraying (IRS). Vector control interventions. Bethesda: PMI, Africa IRS (AIRS) Project, Abt Associates Inc; 2015.

32. Rosenstock IM. The health belief model and preventive health behavior. Health Educ Behavior. 1974;2:354-86.

33. Skinner C, Tiro J, Champion VL. The health belief model. In: Glanz K, Rimer BK, Viswanath KV, editors. Health behavior: theory, research, and practice. San Francisco: Jossey-Bass; 2015. p. 75-94.

34. Huber PJ. The behavior of maximum likelihood estimates under nonstandard conditions. In: Proceedings of the fifth Berkeley symposium on mathematical statistics and probability. University of California Press: Berkeley; 1967. p. 221-33.

35. White $\mathrm{H}$. A heteroskedasticity-consistent covariance matrix estimator and adirect test for heteroskedasticity. Econometrica. 1980;48:817-30.

36. Daykin N, Orme J, Evans D, Salmon D, McEachran M, Brain S. The impact of participation in performing arts on adolescent health and behaviour: a systematic review of the literature. J Health Psychol. 2008;13:251-64.

37. Glik D, Nowak G, Valente T, Sapsis K, Martin C. Youth performing arts entertainment-education for HIV/AIDS prevention and health promotion: practice and research. J Health Commun. 2002;7:39-57.

38. Joronen K, Rankin SH, Astedt-Kurki P. School-based drama interventions in health promotion for children and adolescents: systematic review. J Adv Nurs. 2008;63:116-31.

39. Taboada A, Taggart T, Holloway I, Houpt A, Gordon R, Gere D, et al. A critical review of the characteristics of theater-based HIV prevention interventions for adolescents in school settings. Health Promot Pract. 2016;17:537-47.

40. Parent SN, Ehrlich R, Baxter V, Kannemeyer N, Yassi A. Participatory theatre and tuberculosis: a feasibility study with South African health care workers. Int J Tuberc Lung Dis. 2017;21:140-8.

41. Yoshida I, Kobayashi T, Sapkota S, Akkhavong K. Evaluating educational media using traditional folk songs ('lam') in Laos: a health message combined with oral tradition. Health Promot Int. 2012;27:52-62.

42. Community engagement: making malaria history. PATH; 2018.

43. Atkinson JA, Vallely A, Fitzgerald L, Whittaker M, Tanner M. The architecture and effect of participation: a systematic review of community participation for communicable disease control and elimination. Implications for malaria elimination. Malar J. 2011;10:225.

44. Ndira S, Ssebadduka D, Niyonzima N, Sewankambo N, Royall J. Tackling malaria, village by village: a report on a concerted information intervention by medical students and the community in Mifumi, Eastern Uganda. Afr Health Sci. 2014;14:882-8.

45. Mens PF, Scheelbeek PF, Al Atabbi H, Enato EF. Peer education: the effects on knowledge of pregnancy related malaria and preventive practices in women of reproductive age in Edo State, Nigeria. BMC Public Health. 2011;11:610.

46. Gaspar FW, Chevrier J, Quiros-Alcala L, Lipsitt JM, Barr DB, Holland N, et al. Levels and determinants of DDT and DDE exposure in the VHEMBE Cohort. Environ Health Perspect. 2017;125:077006.

47. Rauch S, Bradman A, Coker E, Chevrier J, An S, Bornman R, et al. Determinants of exposure to pyrethroid insecticides in the VHEMBE Cohort, South Africa. Environ Sci Technol. 2018;52:12108-21.

\section{Publisher's Note}

Springer Nature remains neutral with regard to jurisdictional claims in published maps and institutional affiliations. 